\title{
Somaclonal variability of Ungernia victoris: the necessity of comprehensive genetic analysis
}

\author{
O.M. Bublik, I.O. Andreev, E.V. Spiridonova, V.A. Kunakh
}

Institute of Molecular Biology and Genetics, NAS of Ukraine

150, Academician Zabolotny Str., Kyiv 03680 Ukraine

kunakh@imbg.org.ua

\begin{abstract}
An analysis of five 10-year-old U. victoris cell lines of common origin revealed mixoploidy, significant level of cell polyploidization, quantitative and qualitative changes in individual RAPD-fragments. No regularity was observed in the lines clustering depending on the nutrient medium phytohormone composition or genealogy of the lines. The cytogenetic, molecular and genetic approaches are recommended to ensure reliable determination of somaclonal changes, because the variations in ploidy levels do not always result in the RAPD-polymorphism.
\end{abstract}

Keywords: somaclonal variation, Ungernia victoris, RAPD-analysis, cytogenetic analysis

Introduction. The in vitro culture of plant tissue and cells has received wide application in biotechnology for microclonal reproduction and improvement of plants, obtaining biologically active phytogenous substances, mutagenesis and selection of cells with certain properties, cryoconservation, and other methods of preserving gene pool. Since in vitro cultivation of plant tissues and cells is known to result in various changes in genome, the control of genetic stability of plant material is of special importance [1, $2]$. The polymerase chain reaction with random primers (RAPD-PCR) is the most frequently used method of

(C) O.M. BUBLIK, I.O. ANDREEV, E.V. SPIRIDONOVA, V.A. KUNAKH, 2008 molecular and genetic analysis [3-7], however, little is known about the accuracy of this method in estimating genetic stability of cultivated tissues, since variability of in vitro culture may be presented by not only changes in of DNA sequence but reconstructions on the level of karyotype as well.

The aim of this work was to compare results of estimating genetic stability of cultivated plant tissues, obtained via cytogenetic and RAPD-analysis. In particular, we presented the results of investigation on a group of long-time cultivated $U$. victoris Vved. ex Artjushenko cell lines, Amaryllidaceae family, which is a rare medicinal plant, endemic of Pamirs-Altai region. All the lines analyzed were obtained from one 


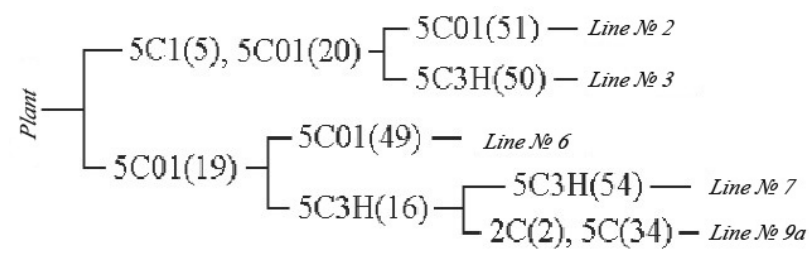

Fig.1 Genealogy of $U$. victoris cell lines: nutrient media and number of passages (in brackets)

bulb and grown on agarose nutrient media of different composition.

Materials and Methods. We analyzed five lines of cultivated $U$. victoris cells, obtained from one plant out of natural population (Tajikistan), which were grown on nutrient media with different composition of microelements, sucrose, and biologically active additives for 10 years [8].

A cytogenetic analysis was performed via calculation of the number of chromosomes in metaphase plates on preparations, made from different parts of callus tissue using a modified method of squashed aceto-orcein preparations [9]. Callus tissues were selected at the same time on the $5^{\text {th }}, 8^{\text {th }}$, and $13^{\text {th }}$ days of passage in the period of high mitotic activity of cells. The data on chromosome number in three samples were combined in the general pool.

As $U$. victoris chromosomes are rather long, the calculation accuracy depended on their quantity. The metaphases with up to $3 n$ chromosome number were counted with accuracy of one chromosome, metaphases with $4 n-6 n$ number - two chromosomes, the ones with over $6 n$ number - three-four chromosomes. For the purposes of statistical processing, the row of chromosomal numbers, obtained in the research, was divided into the following classes: near-haploid (up to 17 chromosomes), near-diploid (17-27 chromosomes), near-triploid (28-38 chromosomes), near-tetraploid (39-49 chromosomes), near-pentaploid (50-60 chromosomes), near-hexaploid (61-71 chromosomes), near-heptaploid (72-82 chromosomes), and near-octaploid (83-93 chromosomes), etc.

The significance of discrepancies was defined according to Student's t-criterion.

DNA extraction from calli and RAPD-PCR were performed by the previously described methods; earlier selected 24 ten-bases primers of random sequence were used [10]. PCR was repeated at least twice, taking into account only well visible amplicons reproduced in repeated reactions. Quantitative differences in amplicon spectra were considered if difference in fluorescence intensity was at least three times.

The data for quantitative estimation of RAPD-polymorphism were presented in a binary matrix, where presence or absence of a fragment of certain type in spectrum was marked as " 1 " or " 0 ", respectively. The genetic distances were determined using obtained matrix by Nei's method [11]; clustering analysis was performed by UPGMA; PopGen software was used for calculations [12].

Results and Discussion. The chromosomes of five 10 -year-old $U$. victoris cell lines of common origin, grown at nutrient media of different composition were counted (Fig.1).

The literature data for diploid number of $U$. victoris chromosomes is $2 n=22$ [13]. The analysis revealed investigated callus lines to be mixoploid cell populations. The number of chromosomes in specific cells ranged from haploid to hyperhaploid sets (Fig.2), except for line No.9a, where maximal number of chromosomes was only about near-haploid set. Aneuploid cells of all ploidy levels comprised a considerable part of the population, their relative amount in all lines was $50 \%$.

The significant differences were determined in structure of cell populations of several $U$. victoris lines, obtained from one bulb (Fig.3). The majority of cells in lines No. 2 and 9a had di- and near-diploid set of chromosomes ( 82.3 and $85.4 \%$, respectively), and the lines did not differ in distribution of the number of chromosomes. The lines No.6 and 7 were more heterogeneous in their composition, their modal class included tetra- and near-tetraploid cells (57.8 and $49.5 \%$, respectively). Besides, they differed in the size of near-diploid, near-triploid, and near-pentaploid classes. The line No.3 proved to be the most heterogeneous one, as its cells were presented in three main classes, namely, di- and near-diploid cells $(41.5 \%)$, tri- and near-triploid cells (32.1\%), tetra- and near-tetraploid cells (17.9\%).

According to the structure of cell populations, the lines can be divided into three groups: lines No.2 and 

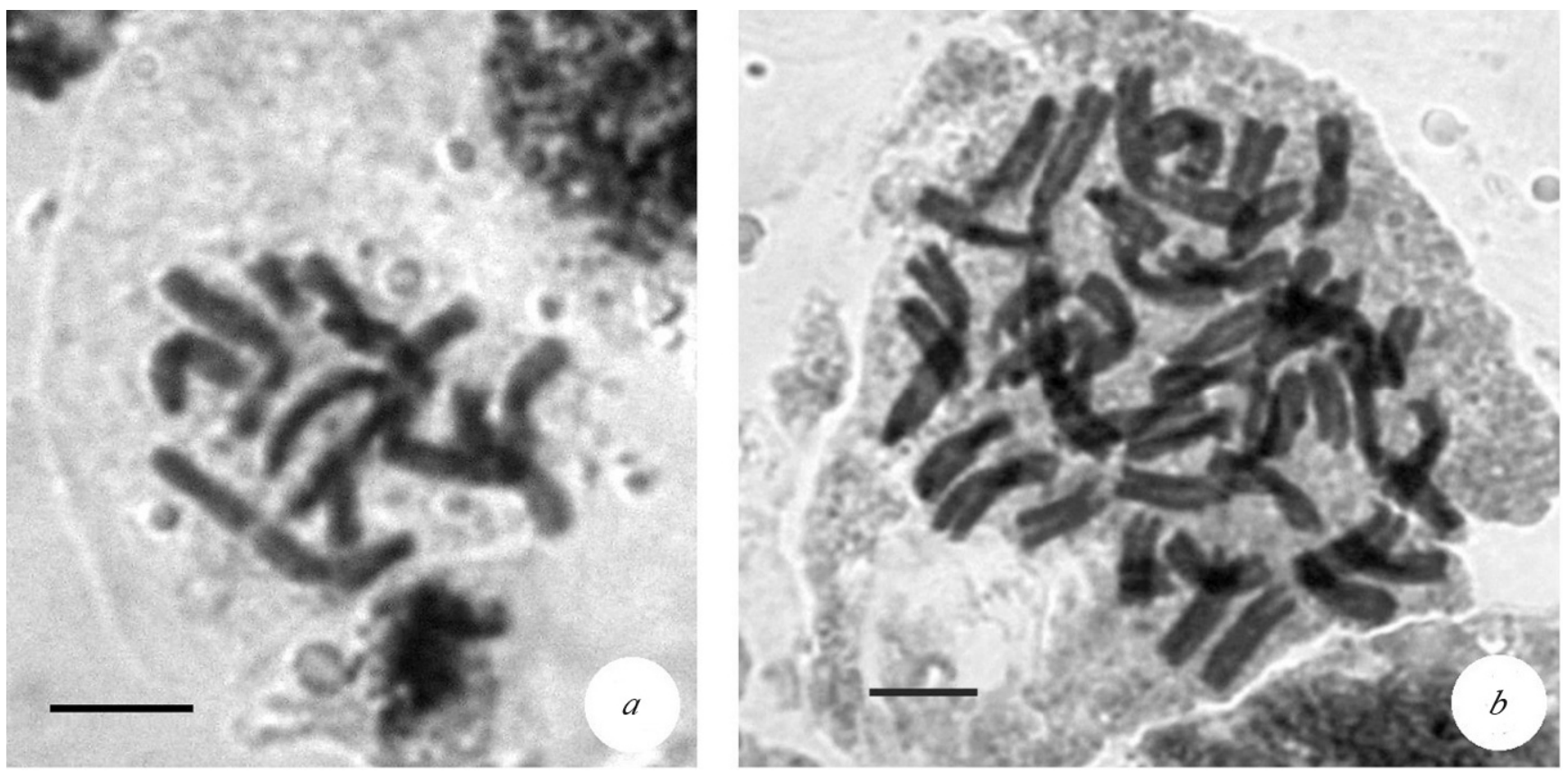

Fig. 2 Metaphases with different number of chromosomes in $U$. victoris tissue culture $(2 \mathrm{n}=22): a-11$ chromosomes; $b-$ about 44 chromosomes. Ruler $-10 \mu \mathrm{m}$.

9a, where the majority of cells had di- and near-diploid set of chromosomes; lines No.6 and 7 with prevailing tetra- and near-tetraploid cells, and line No.3, presented by near-diploid and near-triploid classes mainly. No connection between such distribution of lines and their genealogy was observed.

Besides, RAPD-PCR was used for molecular and genetic analysis of cultivated cells of investigated $U$. victoris lines (Fig.4) with 24 decanucleotide primers, the number of amplified fragments depending on a primer ranged from 4 to 16 (9.9 per primer on average), and sizes varied from 280 to 1990 b.p. The total amount of considered amplicons was 238 . Differences between callus lines were detected in nine (3.8\%) fragments from nine primers spectrum. The amount of polymorphic fragments, demonstrating differences between specific line pairs, ranged from two to seven. It should be noted that polymorphism of RAPD-products was principally reflected in quantitative variability of amplicons, namely, in the changes in fluorescence intensity (Fig.4), except for two amplicons, where differences were seen in the presence of different objects in DNA amplification spectra.
The genetic distances between callus lines were calculated on the basis of RAPD-analysis (Table), their values varied from 0.84 to $2.99 \%$ (average value $1.84 \%)$.

A dendrogram of genetic similarity, built using UPGMA according to genetic distances, revealed two clusters in the cell lines, the first one containing lines No.2, 6, and 7, and the second - lines No.3 and 9a (Fig.5). No regularity was observed in the lines clustering depending on the growing "history". Also there was no correlation between the changes of some fragments and th conditions of cultivation.

Therefore, the results of cytogenetic, molecular and genetic analysis of five callus lines of $U$. victoris, obtained from one plant, gave evidence to their divergence due to growing on media of different composition for 10 years. The investigated lines were presented by heterogeneous mixture of cells of different ploidy level in different ratio; some lines had an evident modal class of diploid or tetraploid cells, while we failed to reveal a separate modal class in the rest.

The main interline difference, found by RAPD-analysis, is a variability of quantitative 

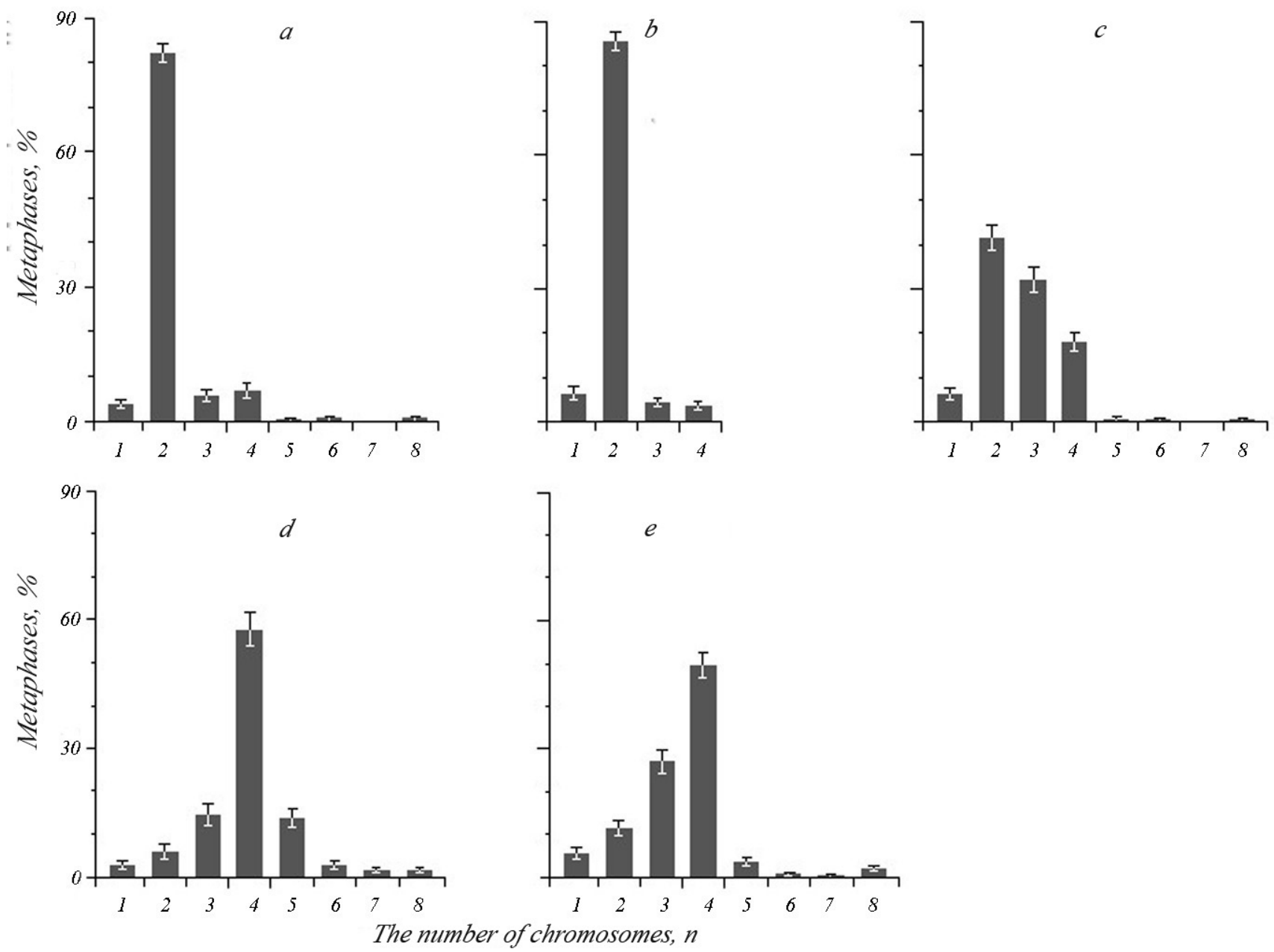

Fig. 3 Distribution of metaphases regarding the number of chromosomes in $U$. victoris cell lines: $a-\mathrm{No} .2, \mathrm{~N}=328 ; b-\mathrm{No} .9 \mathrm{a}, \mathrm{N}=281 ; c-$ No.3, $\mathrm{N}=340 ; d-$ No.6, $\mathrm{N}=192 ; e-$ No.7, $\mathrm{N}=279$ ( $\mathrm{N}-$ number of studied metaphases)

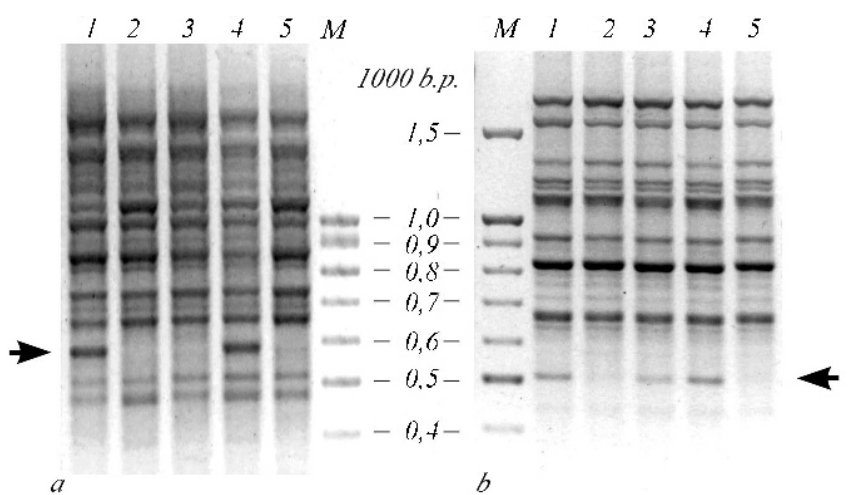

Fig.4 Quantitative (a) and qualitative (b) polymorphism of fragments in RAPD-spectra of $U$. victoris cell lines (primers A16 and A11, respectively): 1-5 - lines No. 2, 3, 6, 7, and 9a, respectively; $M-$ molecular weight marker. Arrows indicate polymorphic amplicons.
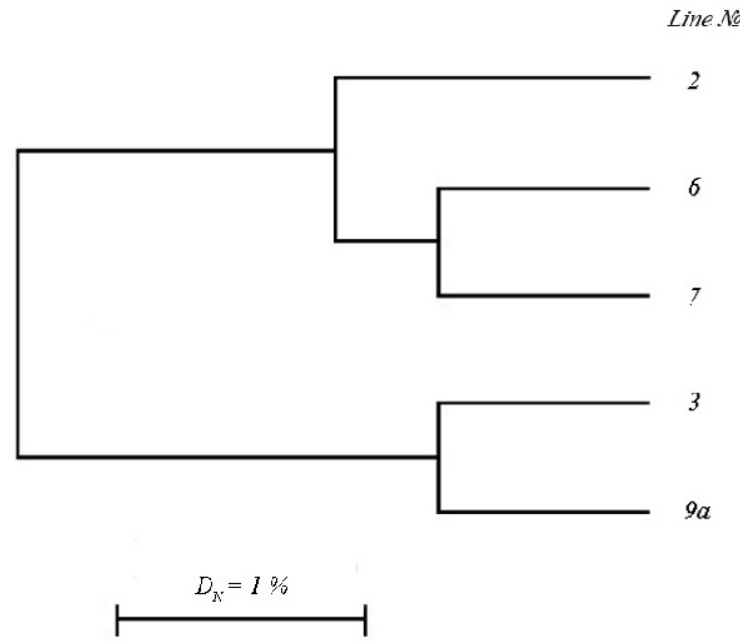

Fig. 5 Dendrogram of genetic similarity of callus lines of $U$. victoris, obtained from one plant, built using UPGMA method according to Nei's genetic distances 
Nei's genetic distances between callus lines of U. victoris, calculated using results of RAPD-analysis

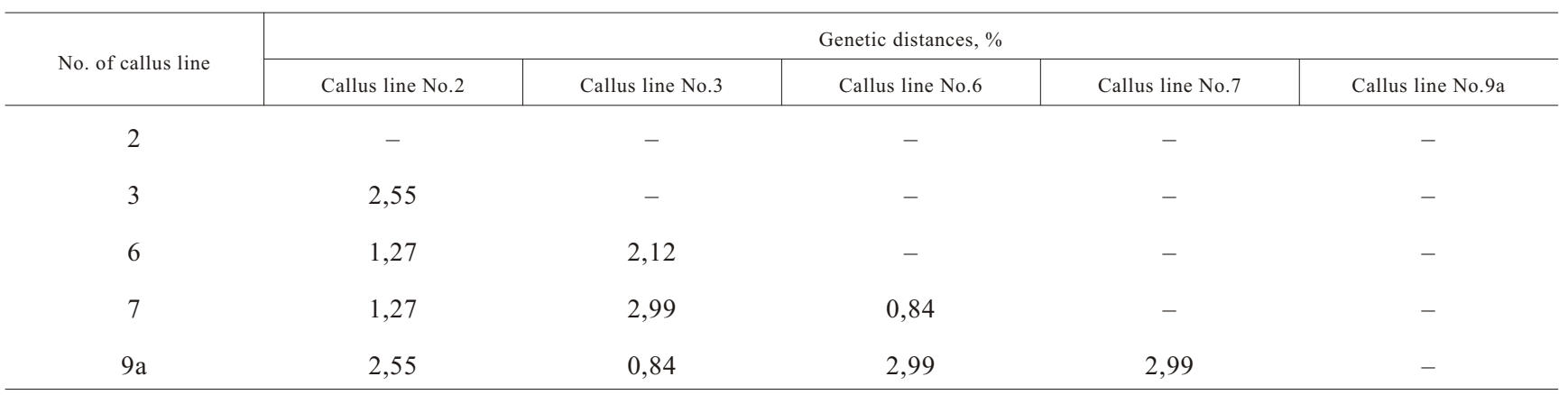

representation of amplicons with some cases of their presence/absence in DNA amplification spectra. We believe that the most probable reason of quantitative variations of separate fragments in RAPD-spectra is a change of ratio between different classes of cell population, when some of them contain this fragment, while others do not. The analysis of random sites showed the fraction of variable parts of genome to be $3.8 \%$ and genetic distances between separate lines ranged from 0.84 to $2.99 \%$.

Neither cytogenetic nor RAPD-analysis revealed regularities in the cell line clustering depending on the medium composition or genealogy. These results contradict the data of research, showing the influence of phytohormone composition of nutrient medium on ploidy of cultivated tissues $[14,15]$ and formation of specific RAPD-profiles [16, 17]. We assume the genome changes, observed on the level of chromosomes as well as on the DNA level are not modulated by the components of nutrient media, presence, concentration or ratio of phytohormones, being of accidental nature.

No relationship was observed between the genome changes of callus lines of $U$. victoris, determined via cytogenetic and molecular and genetic analysis (Fig.2, $3)$; with the exception of lines No.6 and 7, that having similar RAPD-profiles differed by proportion of cell classes with different chromosome number, while RAPD-analysis revealed lines, similar in cytogenetic structure of cell populations, to be genetically distant.

Our results are in good agreement with the experimental data of other authors, testifying to the fact that cultivation of plant tissues in vitro induces genome changes, which influence both karyotype and DNA sequences. However, it should be noted that the changes in amount of chromosomes and variability of DNA sequences in tissue culture may be quite independent.

The analysis of experimental works revealed only several cases of simultaneous detection of abovementioned variability types by cytogenetic and molecular and genetic methods for the purpose of investigation on somaclonal variability. For instance, the changes on both chromosome and molecular levels in in vitro culture were simultaneously observed in regenerant plants $[1,2]$. On the other hand, some data show the absence of changes in molecular markers related to the variations in ploidy of callus cultures [5, $7,18,19]$ and regenerant plants [3-7], as well as to the structural reorganization of chromosomes $[6,7]$. Only one analyzed work described a different picture regenerants of Melia azedarach were characterized by both high chromosome stability and high level of RAPD-polymorphism [20].

The question remains: how can these discrepancies in data of different researchers be explained, and of what consequences may they be for biotechnological practice? First and foremost, it is related to the possibilities of both analytical methods and specificity of changes which they may detect. For instance, karyotype variability, manifested by change in chromosome number, does not entail changes in DNA sequences. It is also true that point mutations, microdeletions, inversions, etc are hardly revealed via cytogenetic analysis since it allows estimating heterogeneity of cell population and analyzing its structure, while molecular and genetic analysis reveals changes on DNA level, related to the major part of cell population, but is not sensitive to the emerging and vanishing of minor cell classes with reconstructed 
genome. These methods characterize different aspects of genome variability that may be of considerable impact on the characteristics of cultivated tissues and regenerant plants. Therefore, accurate and reliable estimation of genetic stability of plant material, obtained from in vitro tissue cultures, requires simultaneous application of several approaches.

Conclusions. Long-term cultivation of the $U$. victoris tissue cultures is characterized by mixoploidy, significant level of cell polyploidization, divergence of genetic structures of cell populations of callus lines, obtained from one bulb as well as by quantitative and qualitative changes in single RAPD-fragments. There is evident stochastic nature of certain variations of a genome with no dependence on the concentration and phytohormone ratio either at the level of chromosome number or the DNA level. The cytogenetic, molecular and genetic approaches are recommended to ensure complete and accurate determination of somaclonal changes, because the variations in ploidy levels do not always result in RAPD-polymorphism.

\section{О. М. Бублик, І. О. Андрєєв, К. В. Спірідонова, В. А. Кунах}

Сомаклональна мінливість Ungernia victoris:

необхідність комплексного генетичного аналізу

Резюме

Аналіз n'яти клітинних ліній U. victoris спільного походження, вирощуваних протягом 10 років, виявив міксоплоїдію, значний ступінь поліплоїдизачї клітин, кількісні і якісні зміни окремих $R A P D$-фрагментів. Закономірностей при групуванні клітинних ліній залежно від складу середовища або історії вирощування не спостерігалося. Оскільки зміни рівня плоїдності не завжди супроводжуються появою RAPD-поліморфізму і навпаки, щоб надійніше і повніше визначити сомаклональні зміни, рекомендується одночасне застосування иитогенетичного та молекулярно-генетичного методів.

Ключові слова: сомаклональна мінливість, Ungernia victoris, RAPD-аналіз, цичтогенетичний аналіз.

\section{Е. Н. Бублик, И. О. Андреев, Е. В. Спиридонова, В. А. Кунах}

Сомаклональная изменчивость Ungernia victoris:

необходимость комплексного генетического анализа

Резюме

Анализ пяти клеточных линий $U$. victoris общего происхождения, выращиваемых в течение 10 лет, обнаружил миксоплоидию, значительную полиплоидизацию клеток, количественные и качественные изменения отдельных RAPD-фрагментов. За- кономерностей группирования клеточных линий в зависимости от состава среды или истории выращивания не наблюдалось. Поскольку изменения уровня плоидности не всегда сопровождаются возникновением RAPD-полиморфизма и наоборот, для надежной оценки сомаклональних изменений рекомендуется параллельное применение цитооенетичного $u$ молекулярно-генетического методов.

Ключевые слова: сомаклональная изменчивость, U. victoris, $R A P D$-анализ, иитогенетический анализ.

\section{REFERENCES}

1. Pontaroli A. C., Camadro E. L. Somaclonal variation in Asparagus officinalis plants regenerated by organogenesis from long-term callus cultures // Genet. and Mol. Biol.2005.-28.-P. 423-430.

2. Al-Zahim M. A., Ford-Lloyd B. V., Newbury H. J. Detection of somaclonal variation in garlic (Allium sativum L.) using RAPD and cytological analysis // Plant Cell Rep.-1999.18.-P. 473-477.

3. Jazdzewska E., Sadoch Z., Niklas A., Majewska-Sawka A. Plant regeneration from sugar beet leaf protoplasts: analysis of shoots by DNA fingerprinting and restriction fragment length polymorphism // Can. J. Bot.-2000.-78.-P. 10-18.

4. Raimondi J. P., Masuelli R. W., Camadro E. L. Assessment of somaclonal variation in asparagus by RAPD fingerprinting and cytogenetic analyses // Sci. Horticult.-2001.-90.-P. 1929.

5. Fourre J. L., Berger P., Niquet L., Andre P. Somatic embryogenesis and somaclonal variation in Norway spruce: morphogenetic, cytogenetic and molecular approaches // Theor. and Appl. Genet.-1997.-94.-P. 159-169.

6. Gavrilenko T., Thieme R., Tiemann H. Assessment of genetic and phenotypic variation among intraspecific somatic hybrids of potato, Solanum tuberosum L. // Plant Breeding.1999.-118.-P. 205-213.

7. Hao Y.-J., Deng X.-X. Occurrence of chromosomal variations and plant regeneration from long-term-cultured citrus callus // In Vitro Cell. and Develop. Biol. - Plant.-2002.-38.P. 472-476.

8. Бублик Е. Н., Адонин В. И., Кунах В. А. Цитогенетическая изменчивость клеточных линий Ungernia victoris при выращивании на питательных средах различного состава // Цитология и генетика.-2008.-42, № 1.-С. 29-36.

9. Кунах В. А., Левенко Б. А. Модификация метода давленых препаратов для изучения хромосом в клетках культуры тканей растений // Цитология и генетика.-1975.-9, № 1.C. $56-58$.

10. Бублик О. М., Андрєєв I. О., Спірідонова К. В., Музика В. I., Колоніна I. В., Кунах В. А. Генетична гетерогенність рідкісного ендемічного виду Ungernia victoris (Amaryllidaceae): RAPD-аналіз // Укр. бот. журн.-2008.65, № 3.-C. 445-451.

11. Nei M. Estimation of average heterozygosity and genetic distance from a small number of individuals // Genetics.1978.-89.-P. 583-590.

12. Yeh F. C., Boyle T. J. B. Population genetic analysis of co-dominant and dominant markers and quantitative traits // Belg. J. Bot.-1997.-129.-P. 157.

13. Агапова Н. Д., Архарова К. Б., Вахтина Л. И., Земскова Е. A., Тарвис Л. В. Числа хромосом цветковых растений 
флоры СССР: семейства Aceraceae-Menyanthaceae.-Ленинград: Наука, 1990.- 48 с.

14. Mishiba K., Okamoto T., Mii M. Increasing ploidy level in cell suspension cultures of Doritaenopsis by exogenous application of 2,4-dichlorophenoxyacetic acid // Physiol. Plant.-2001.-112.-P. 142-148.

15. Mishiba K.-I., Tawada K.-I., Mii M. Ploidy distribution in the explant tissue and the calluses induced during the initial stage of internode segment culture of Asparagus officinalis L. // In Vitro Cell. and Develop. Biol. - Plant.-2006.-42.-P. 83-88.

16. Bogani P., Simoni A., Lio P., Germinario A., Buiatti M. Molecular variation in plant cell populations evolving in vitro in different physiological context // Genome.-2001.-44.P. 549-558

17. Mangolin C., Ottoboni L., Machado M. RAPD markers to evaluate callus tissue of Cereus peruvianus Mill. (Cactaceae) maintained in different growth regulator combinations // Biochem. Genet.-2002.-40.-P. 351-358.

18. Wilhelm E. Somatic embryogenesis in oak (Quercus spp.) // In Vitro Cell. and Develop. Biol. - Plant.-2000.-36.-P. 349357.

19. Hao Y.-J., Wen X. -P., Deng X.-X. Genetic and epigenetic evaluations of citrus calluses recovered from slow-growth culture // J. Plant Physiol.-2004.-161.-P. 479-484.

20. Olmos S. E., Lavia G., Di renzo M., Mroginski L., Echenique $V$. Genetic analysis of variation in micropropagated plants of Melia azedarach L. // In Vitro Cell. and Develop. Biol. Plant.-2002.-38.-P. 617-622.

UDC $(575.22+576.5) 582.573 .21$ Received 08.05.08 